\title{
O PAPEL DOS AGENTES DO TURISMO A PARTIR DO MAPA DO TURISMO BRASILEIRO EM MARABÁ-PA
}

\author{
Hugo Rogério Hage Serra \\ Universidade Federal do Sul e do Sudeste do Pará (UNIFESSPA) \\ Laboratório de Estudos Regionais e Agrários do Sul e do Sudeste do Pará, Marabá-PA, Brasil \\ serra@unifesspa.edu.br \\ Izabela Rodrigues Paz \\ Universidade Federal do Sul e do Sudeste do Pará (UNIFESSPA) \\ Bolsista de Iniciação Científica - Fapespa \\ Laboratório de Estudos Regionais e Agrários do Sul e do Sudeste do Pará, Marabá-PA, Brasil \\ izabelapaz@unifesspa.edu.br
}

\begin{abstract}
RESUMO
Este trabalho tem como objetivo principal identificar e analisar a atuação dos agentes produtores do turismo em Marabá, bem como esses agentes reproduzem de forma política e espacial os critérios do Mapa do Turismo Brasileiro (MTB). O papel que Marabá, enquanto cidade média, exerce na região Sul e Sudeste do Pará norteou esta pesquisa, bem como o interesse pela análise regional de como as políticas públicas de turismo operam - ou não - em uma região. Parte-se de uma metodologia que considera as contradições histórico-regionais de Marabá, assim como a força econômico-regional que implica nas decisões para o turismo na cidade. Para tanto, a revisão breve de literatura sobre políticas públicas e das cidades médias foram necessárias. $O$ uso de observação direta de reuniões dos agentes do turismo e as entrevistas compõem os procedimentos metodológicos. Afirma-se que o fato de Marabá ser a principal cidade econômica das regiões Sul e Sudeste do Pará influencia consideravelmente na organização e nas decisões políticas sobre o turismo para além de seus limites administrativos por meio da atuação dos agentes do turismo, considerados agentes de decisão na tomada dos critérios do MTB.
\end{abstract}

Palavras-chave:Cidades médias. Análise regional. Políticas Públicas. Marabá.

\section{THE ROLE OF TOURISM AGENTS FROM THE BRAZILIAN TOURISM MAP PROGRAM IN MARABÁ-PA}

\begin{abstract}
This work has as the main goal, to identify and analyze the performance of agents producers of tourism in Marabá as well as how these agents reproduce politically and spatially the criteria of the Brazilian Tourism Map (BTM). The role that Marabá, as a medium city, plays in the South and Southeast of Pará guided this research. Together with the interest by regional analysis of how public tourism policies operate - or not - in a region. It starts with a methodology that considers Maraba's historical-regional contradictions, as well as the economic-regional strength that implies in decisions for tourism in the city. For this, a brief review of the literature on public and city policies was necessary. The use of direct observation of tourism agents' meetings and interviews composes the methodological procedures. It is stated that the fact of Marabá being the main economic town in the South and Southeast regions of Pará influences considerably the organization and political decisions on tourism beyond its administrative limits through the actions of tourism agents, considered as decision-makers in the decision-making of the BTM criteria.
\end{abstract}

Keywords:Medium city. Regional analysis.. Public Policies. Marabá.

\section{INTRODUÇÃO}

A cidade de Marabá está localizada na Região Intermediária Sul e Sudeste do Pará (IBGE, 2020). É conhecida, também, por ter uma das principais economias dessa região devido ao seu potencial de atratividade, caracterizada por seu comércio de móveis, eletrônicos, eletrodomésticos e produtos de informática, alcançando 501 mil pessoas, assim como alcança 410 mil pessoas em seu polo comercial de roupas e calçados, segundo uma pesquisa realizada pelo IBGE - Região de Influência das Cidades 
REGIC - no ano de 2018, publicada em maio de 2020 (IBGE, 2020). Estrategicamente, é uma cidade média (PEREIRA e TRINDADE JÚNIOR., 2007). Este último é, diga-se de passagem, o conceito mais importante ao se entender como uma atividade tal qual o turismo se manifesta no espaço onde Marabá está localizada e que serve de parâmetro a ser problematizado neste trabalho.

Por ser uma cidade nodal para serviços, comércios e, de forma considerável, para a indústria de transformação, Marabá tornara-se uma referência regional ao longo do tempo, especialmente, no final do século XX. Logo, equipamentos urbanos típicos do turismo - mas, não exclusivos - tais como os hotéis e restaurantes, passaram a configurar a paisagem dessa cidade, principalmente, a partir de surtos econômicos (BECKER, 2013), com destaque para os que provocaram uma intensa migração e fixação de diferentes agentes sociais nesse recorte espacial.

No que se refere ao turismo, o Estado brasileiro não se furta de sua função ao elaborar e implementar políticas territoriais por meio de uma abordagem regional, considerando sua vastidão territorial, ainda que tal atividade, comparada a outros países, não tenha um peso considerável na composição do Produto Interno Bruto - PIB (IPEA, 2015); mais do que isso, o Estado organiza o espaço regionalmente por causa de sua ampla diversidade territorial.

Para a atividade turística, mais recentemente, o Ministério do Turismo (MTur), lançou o Mapa do Turismo Brasileiro - MTB (BRASIL, 2019), o qual possui como diretriz central agrupar regiões turísticas que possuem potencial turístico em suas unidades federativas. Pela sua força econômica e pela sua representatividade de uma cidade média, Marabá tornou-se um dos exemplos na região norte que integram o MTB.

Contudo, para as regiões Sul e Sudeste do Pará, o MTB apresenta algumas incongruências regionais que a representatividade de Marabá não consegue efetivar regionalmente. Os critérios se fazem presentes na política, porém, são distorcidos ou mal apropriados político-espacialmente em Marabá. Um deles diz respeito ao papel dos agentes do turismo ante ao MTB, os quais devem estar agrupados em organismos institucionais relacionados direta e indiretamente ao turismo. É, especificamente, nesse imbróglio que as decisões políticas não se difundem a contento na região. Neste trabalho, em relação à Marabá, considera-se um questionamento norteador que envolve a participação de agentes ligados ao turismo e às entidades que eles representam, ou seja: qual o papel que os agentes produtores do turismo em Marabá possuem no desenvolvimento dessa atividade a partir da implementação do MTB e como eles se reproduzem política e espacialmente?

Uma das estratégias captadas diz respeito à composição dos representantes do turismo no Conselho Municipal de Turismo de Marabá (Comtur); nele, várias entidades participam e cumprem uma reunião mensal com o objetivo de impulsionar e planejar os próximos passos da atividade turística em Marabá. Contudo, o poder de decisão entre os agentes durante as reuniões se manifesta desigualmente, o que implica em uma execução da lei municipal de forma a atender aos interesses daqueles que estariam em um circuito superior da economia urbana (SANTOS, 2002) do turismo, reproduzindo uma determinada representatividade socioespacial.

Por estes termos, este trabalho parte de um objetivo geral qual seja o de identificar e analisar a atuação dos agentes produtores do turismo em Marabá a partir da reprodução dos critérios do MTB.

A metodologia utilizada é fruto de projeto de pesquisa homônimo a este texto desenvolvido no âmbito da Universidade Federal do Sul e Sudeste do Pará - Unifesspa, o qual teve preocupação na leitura regional do turismo com suas contradições entre o espaço representado e o espaço da realidade transformados pelas práticas dos agentes do turismo, tendo Marabá como principal cidade na composição de uma política pública, tal como o MTB. Considera-se a importância geográfica de Marabá como cidade média e sua relação com a economia do turismo (IPEA, 2015; TRINDADE JR e PEREIRA, 2007); por meio deles, empreende-se a uma análise regional na composição do MTB.

A produção geográfica sobre o turismo faz parte da história das várias delimitações do objeto de estudo e metodologia da Geografia (OURIQUES, 2003). Nesse caso, a análise geográfica do turismo feita aqui é por meio da região e do espaço. Por seu turno, observa-se o turismo como um fenômeno 
socioespacial em que a ciência geográfica é o ponto de partida, de desenvolvimento de um raciocínio sistemático, bem como o produto da análise metodológica aqui empreendida.

Há uma seletividade espacial no recorte regional dos municípios que compõem o mapa do turismo em que Marabá está inserido: a Região Turística Carajás. No que se refere à espacialidade "como as outras instâncias, o espaço, embora submetido à lei da totalidade, dispõe de uma certa autonomia" (SANTOS, 1978 apud CORRÊA, 2000, p. 27-28). Na região citada, a cidade de Marabá se destaca como principal polo turístico, convergindo todos os fatores e consequências da atividade turística para o munícipio, contrariando assim, o conceito de regionalização e a descentralização do turismo que está previsto no MTB (SERRA, 2017).

Por fim, este trabalho, para além desta introdução e conclusão, está subdivido em três seções. A primeira delas é um esforço para sintetizar em linhas gerais o conceito de cidade média como algo necessário para entender o papel regional de Marabá no Sul e no Sudeste do Pará. A segunda seção preza pelo debate da política, principalmente, dos seus principais elementos que formam a agenda da política pública sob um ângulo de uma abordagem em que se prima pelas contradições do espaço regional como categoria de análise. Por fim, apresentam-se os dados referentes ao papel dos agentes do turismo em Marabá relacionados ao MTB a fim de ser compreender as contradições apresentadas.

\section{BREVES NOTAS SOBRE A FORMAÇÃO SOCIOESPACIAL E SOBRE A CONSTITUIÇÃO DE MARABÁ COMO UMA CIDADE MÉDIA.}

O debate sobre a centralidade de Marabá na condição de cidade mais importante da região e que, na atualidade, interfere em questões econômico-políticas tais como o turismo, passa, inicialmente, pelo entendimento de como se deu sua formação socioespacial, bem como sua relação com a região a qual está vinculada em seu processo inicial de constituição territorial. Esse debate se torna importante para que se evite uma interpretação de que os fenômenos espaciais sejam aprisionados (ou detidos) por aqueles que enxergam as dinâmicas socioeconômicas, apenas pela História do presente. Do contrário, o conceito de formação socioespacial (SANTOS, 1979a), como retrato da História enquanto processo, é o que auxilia no funcionamento de mecanismos de diversas ordens sociais visíveis na paisagem.

É Santos (1979a) quechama a atenção para o papel da geografia no olhar de forma transversal (e material) no tempo. Para este autor, o enaltecimento das formas - as coisas acabadas e dadas na paisagem - sugere que a dinâmica das coisas - a função ou animosidade - encubra a centralidade da formação. Esta última categoria de análise é, por assim dizer, a espiritualidade ou o que dá vida às coisas através do tempo. Dada a certeza de que Santos (1979a) separa a explicação entre forma e formação para fins didáticos, sabe-se que os dois elementos são indissociáveis e que o espaço geográfico é testemunha material dos processos. Cabe ao pesquisador entender tal dinâmica de acordo com sua escala geográfica ou objeto empírico onde um fenômeno se manifesta.

Como reforço dessa ideia, em outra obra, Santos (1979b), mostra como a formação socioeconômica se difere do modo de produção, ao mesmo tempo em que se problematiza a forma como categoria essencial do espaço geográfico, não interpretando "a coisa através da própria coisa" (SANTOS, 1979b, p. 198). Para este autor, ainda, é pela totalidade (não fechada) que se pode compreender as ações que transformam coisas em objetos ao longo do tempo. As ideias provenientes do debate proferido pelo autor nos ajudam a compreender, por exemplo, como a mudanças na paisagem testemunham as metamorfoses das formas espaciais, sendo estas últimas uma espécie de síntese em um dado momento histórico - do conteúdo de uma formação socioeconômica. Segundo ele:

A nova forma chega junto com um conteúdo importado. A incorporação de uma nova forma à formação socioeconômica significa a incorporação de seu conteúdo à mesma formação socioeconômica. Os modos de produção garantem a continuidade histórica, inclusive a continuidade histórica das formas. Mas é apenas dentro da formação socioeconômica específica que as formas adquirem um papel social efetivo (SANTOS, 1979b, p. 201, grifos do autor).

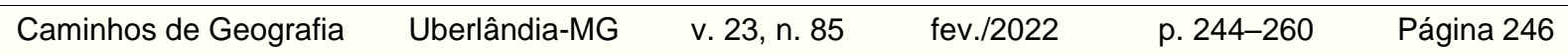


Marabá passou por processos econômicos que reverberaram marcadamente no espaço, tal como a exploração do caucho e da castanha, ambos situados temporalmente no início do século XX, esses processos diluíram-se no tempo, no sentido de que "entranharam" em outras dinâmicas econômicas subsequentes, o que, por certo, deixaram marcas significativas até o presente momento.

O primeiro dos eventos histórico-geográficos - o caucho - emplaca uma trajetória que marcou o nascimento de oligarquias tradicionais ligadas à extração do látex e que resultou num intenso fluxo migratório que moldou o espaço urbano, bem como o contingente populacional de Marabá. A cidade dos "notáveis"1 da borracha passou a assumir um papel importante na região Sudeste do Pará consideravelmente por sua posição geográfica favorável, pois estava na confluência dos rios Itacaiúnas e Tocantins, os quais foram cruciais para o escoamento da borracha. As embarcações foram os principais meios de transporte da região para a capital paraense, Belém, e para outras cidades como Rio de Janeiro, São Paulo, Recife e Fortaleza, além do Sudoeste do Maranhão e do Norte de Goiás (DIAS, 1958). É a partir de então que Marabá tornara-se uma praça comercial e assumiu o papel de entreposto comercial e de transporte, equiparando-se a Belém (VELHO, 1981). Nessas condições, a centralidade do núcleo urbano populacional se fortalece e, consequente a isso, as disputas pelo poder local também se intensificaram. Emmi (1999), por exemplo, esclarece que esses conflitos não foram apenas da luta pela posse da terra, mas, também, para controlar as fontes e a extração do látex. É nesse sentido que as oligarquias locais se adaptaram a novos empreendimentos mercantis a fim de estabelecer uma economia dominante na escala local. A relação intra-urbana e inter-urbana no espaço começa a se definir lentamente. Ao se apropriar das ideias de Corrêa (2007), para o entendimento do funcionamento de uma cidade central em uma rede urbana, tem-se que:

Em razão das distâncias viabiliza-se, em grande parte, uma maior divisão econômica do espaço, submetido a um mais significativo processo de descentralização, origem dispersa e formação de núcleos de atividades derivados de economia de aglomeração, distantes dos centros. [...] Em resumo, maior o tamanho demográfico e mais complexa as atividades econômicas, particularmente as funções urbanas, mais fragmentada e, por conseguinte, mais articulada será a cidade (CORRÊA, 2007, p.24).

Trindade Jr e Ribeiro (2009) consideram que Marabá está incluída no contexto sub-regional, que se trata, nesse sentido, da centralidade que ela assume ao longo da sua formação socioespacial no Sudeste do Pará, em função da sua disponibilidade de serviços, atividades econômicas e sociais desenvolvidas nas últimas décadas. ${ }^{2}$

O segundo evento histórico é marcado pela extração da castanha, período este que foi indispensável para a formação urbana e para a expansão da cidade. A reestruturação do espaço regional mediante às atividades extrativistas advindas da castanha-do-pará, transformaram a paisagem marabaense e a dinâmica regional do Sudeste Paraense. Um dos fatores que contribuiu para essa mudança foi o contexto das grandes enchentes, as quais deram origem ao núcleo urbano planejado Nova Marabá, sob coordenação da Superintendência do Desenvolvimento da Amazônia (Sudam). A centralidade urbana que antes crescia sobre às margens do Rio Tocantins e se concentrava na Marabá Pioneira ou Velha Marabá, agora se descentraliza para novos núcleos urbanos formando novas centralidades, tal como se percebe na Figura $1^{3}$.

\footnotetext{
1 Trindade Jr. et al. (2016) adotam essa definição para reforçar a periodização descrita no texto "A cidade dos 'notáveis' e a produção extrativa da borracha", visto que a emancipação do município foi apenas em 1913. O termo "notável" é inspirado em Santos (1993) e define, no contexto da história, um tipo de "personalidade local" particular. Nesse caso, a hegemonia exercida na política e economia da sub-região Sudeste do Pará, protagoniza Marabá como cidade-região mais importante

2 Para Trindade Jr e Ribeiro (2009), o centro sub-regional dá suporte às metrópoles, sendo assim, um centro urbano capaz de influenciar um número significativo de cidades, em geral, considera-se a quantidade de 15 centros que refletem a desigualdade regional. No caso de Marabá, as cidades da região Sul e Sudeste Paraense são influenciadas e convergem para atividades econômicas e sociais, como serviços de saúde - em exemplo, o Hospital Regional do Sudeste do Pará -, serviços eletrônicos, shopping center, instituições de nível superior, entre outros. Assim, os serviços oferecidos por Marabá equiparam-se aos de Belém e há uma descentralização do fluxo da economia no estado, caracterizando Marabá como uma cidade média e centro sub-regional.

${ }^{3}$ Trindade Jr. et al. (2016) associam a formação socioespacial à qual Marabá está inserida com um intenso processo de fragmentação do território. Este fenômeno se deveu à maneira pela qual a economia extrativista na região se materializou no espaço, principalmente, revelando uma urbanização do território e da sociedade bem particulares.
}

$\begin{array}{llllll}\text { Caminhos de Geografia } & \text { Uberlândia-MG } & \text { v. 23, n. } 85 & \text { fev./2022 } & \text { p. 244-260 } & \text { Página } 247\end{array}$


Figura 1 - Imagem aérea do Núcleo Nova Marabá no final dos anos 1970, em processo de construção.

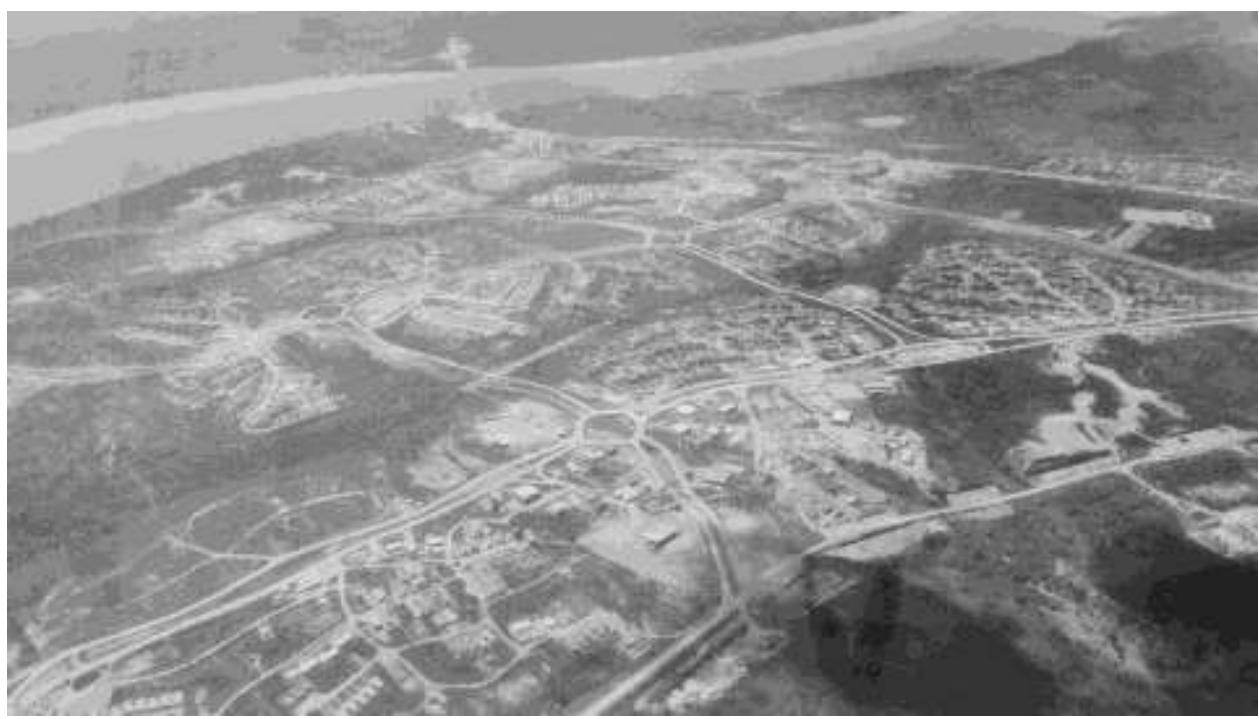

Fonte - Jornal Correio do Carajás (arquivo), 2020.

No processo de urbanização amazônico nos anos de 1960, o Estado se tornou um grande incentivador de mudanças expressivas na região amazônica com a criação demalhas, tais como a malhas ferroviária e rodoviária sobre o território (BECKER, 1998), fazendo com que Marabá se tornasse um dos destinos principais do processo migratório na região.

A partir dos anos de 1970 a cidade de Marabá mostrou-se cada vez mais uma das cidades mais importantes da região Sudeste paraense. A criação e implantação da rodovia Transamazônica entre 1970 e 1971, a PA-70 - atual BR222 - e a PA-150 reforçaram a cidade como ponto estratégico da circulação do capital financeiro e industrial. Os recursos naturais: minerais, madeireiros e energéticos foram elementos essenciais para a produção do espaço regional, pois transformaram o sudeste paraense em um produtor mineral de grande escala e, pela localização geográfica favorável e suas redes tecnopolíticas ${ }^{4}$, Marabá se configurou como entreposto comercial na região e para outras cidades, como já citado anteriormente. Este contexto, por sua vez, encabeça a terceira grande fase importante na formação socioespacial de Marabá e da região onde ela se encontra.

As condições históricas sob as quais Marabá promovera seu desenvolvimento, sem embargos, afetaria na atividade turística, o que é reforçado pela importância de ser, aquela, uma cidade média.

Quando Corrêa (2007) destaca a cidade média, ele diz que: "sua particularidade reside no pressuposto de uma específica combinação entre tamanho demográfico, funções urbanas e organização de seu espaço intra-urbano". Em outras palavras, isolar cada um desses três pontos seria equívoco e ignorância. Há uma particular combinação entre eles que caracteriza determinada região e que leva em consideração a dimensão do espaço intra-urbano, as relações sociais e econômicas e o desenvolvimento de novas funções locais e regionais.

Corrêa (2007) reforça, ainda, um quadro teórico que aponta três elementos para a compreensão do conceito de cidade média, quais sejam: a elite empreendedora, a localização relativa e as interações espaciais. A primeira assume o papel de controle da centralidade política da cidade; essa elite empreendedora estabelece relações econômicas e políticas entre as cidades maiores e os centros metropolitanos. Corrêa (2007) chama atenção para alguns questionamentos: qual a origem e natureza dessa elite? Foi originária de um pequeno comércio, de uma propriedade fundiária rural ou uma pequena indústria? no que se refere à relatividade, o espaço temporal é que constrói uma localização relativa, as vias de circulação de pessoas, capitais e informações traçam uma linha do tempo que varia de acordo com o crescimento da cidade média? Por último, as interações espaciais estão ligadas à multiescalaridade: a escala regional e a escala extra-regional, seja nacional ou internacional? Este último, talvez, seja um dos elementos mais importante desse quadro teórico, pois,

4 Termo inspirado em Becker, Miranda, Machado (1990) e em Becker (1982,1998), que corresponde às redes de transporte, redes elétricas, redes de comunicação e rede urbana

\begin{tabular}{|c|c|}
\hline Caminhos de Geografia & Uberlândia-MG \\
\hline
\end{tabular}


em sua maioria, essas interações são controladas pela elite da cidade e, como já mencionado, essa elite tem uma inter-relação com a rede de cidades para além da cidade média.

Para além do tamanho demográfico e populacional, as cidades médias se caracterizam, principalmente, pelo seu papel influenciador na região entre as escalas geográficas. Marabá pode ser explicada pelos dois conceitos. A cidade tem uma situação geográfica favorável por ser uma zona de entreposto, por obter recursos naturais, uma malha ferroviária importante para a região sudeste do Pará. Desse modo, Marabá detém, relativamente, facilidades de toda ordem, troca com a capital e as demais cidades da região, bem como outros estados. No entanto, as desigualdades e segregações socioespaciais estão presentes na realidade urbana da cidade, o que nos permite avaliar que 0 conceito de cidade média não se circunscreve às dinâmicas econômicas similares ou próprias de um circuito superior da economia urbana (SANTOS, 2002); de outra forma, uma cidade média abriga, sobretudo, todas suas contradições existentes e inerentes aos critérios do conceito.

As relações urbano-regionais se dão de forma geograficamente desigual, isso porque a acumulação do capital gerada na centralidade urbana altera o espaço, as espacialidades e as territorialidades existentes (HARVEY, 2004), abarcando, até mesmo, a realidade rural-agrária na qual Marabá está imersa. Neste caso, o que a define como cidade média vai além dos patamares demográficos, referese ao que Harvey (1980) chama de espaço relativo e de espaço relacional. O papel político e de responsabilidade socioespoacial que Marabá exerce sobre a região sudeste é o que a caracteriza como um centro sub-regional, do tipo cidade média.

O trabalho de Sposito (2007) sobre as cidades médias expõe uma ideia central que, ao mesmo tempo, torna-se transversal aos debates que envolvem a força econômica de cidades representativas. Para as autoras, o potencial explicativo das escalas geográficas, para além de seus atributos cartográficos, ajudam na valorização do que venham a ser cidades médias, posto que a posição relativa e transitória desses espaços faz com que se saiba de relações, sobreposições e justaposições de fenômenos atinentes à realidade urbana desses lugares, os quais possuem características diferentes das metrópoles.

De forma complementar, pode-se afirmar, apoiando-se nas ideias de Whitacker (2007), que o espaço urbano (entre eles, o de uma cidade média), é resultado da ação dialética que se perfaz em formas e funções, as quais não podem ser compreendidas fora dos domínios de uma determinada historicidade. Esse mesmo autor chama atenção para fatos atinentes à realidade de cidades médias, a exemplo da relação entre a fixidez da moradia e a mobilidade do consumo, coisas essas que já demarcam a historicidade de grandes cidades, passam agora a serem mais comuns em cidades médias.

Isso tudo já mencionado insere-se e se torna fio condutor para se entender a atividade turística em Marabá. O governo brasileiro adotou em 2003 a política de delimitar o turismo por meio de regiões (BRASIL, 2003). Um dos programas criados nessa nova configuração foi o "Mapa do Turismo Brasileiro - MTB" (BRASIL, 2019), inserido no Programa de Regionalização do Turismo - PRT (BRASIL, 2004). Esse conjunto de decisões passou a formar o corpo de uma nova política pública para o turismo. O objetivo dos programas, nesse sentido, é descentralizar o turismo e inserir municípios que estejam aptos a ingressar no mapa, desde que cumpram as regras e diretrizes dispostas no MTB. Marabá, por sua vez, está no MTB, participante da Região Turística Carajás, que faz parte das 14 regiões turísticas no estado do Pará (PARÁ, 2019).

É a partir daqui que a relação entre política pública e planejamento se torna estruturante no entendimento conceito de cidade média e de seu papel na região turística, tal como o do MTB, inclusive a fim de se compreender o papel dos agentes das políticas de turismo, suas contradições e como eles coordenam a atividade turística em uma cidade como Marabá.

\section{POLÍTICA PÚBLICA E O PROGRAMA MAPA DO TURISMO BRASILEIRO NO TERRITÓRIO.}

A abordagem sobre o planejamento de políticas públicas é extensa e complexa. Diversos autores já discursaram sobre esse tema e o debate político sobre a formação da agenda da política pública está presente nesse texto, tanto para explicar como isso implica na dinâmica exercida em Marabá através dos agentes de turismo, quanto para a compreensão da importância dessa discussão para a prática no território ${ }^{5}$. De antemão, cabe ressaltar que os elementos discursivos presentes nas políticas públicas possuem uma razoabilidade territorial, visto que sua efetividade só tem efeito mediante a concretude das ações.

${ }^{5}$ Ver Capella (2018), Dias e Matos (2012), Secchi (2013), por exemplo.

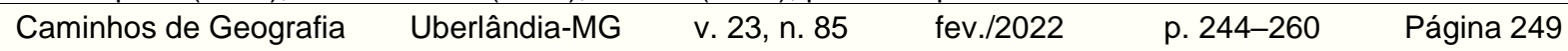


Cruz (2005) fala que o planejamento governamental "é um processo político-ideológico, que exprime anseios, objetivos e visões de mundo dos sujeitos sociais que o conduzem" (CRUZ, 2005, p. 39) e que para "conciliar esses interesses no ordenamento dos territórios pelo e para o turismo deve ser um paradigma orientador do planejamento governamental e de políticas públicas" (CRUZ, 2005, p.40). Essa ideia de organização, planejamento e execução forma o esqueleto do que pode se considerar a base da atividade governamental, visto que a agenda existe em todos os níveis de governo.

Frey (2000), por sua vez, afirma que a política pública deve ser analisada em três dimensões: a dimensão institucional, a dimensão processual e a dimensão material. Todas essas três se referem ao processo de planejamento administrativo e sua execução e, mesmo que essas dimensões não tenham relação direta, elas mantêm uma interdependência entre si que se influenciam de maneira positiva, mas que sofrem alterações no decorrer do tempo.

No que se refere às políticas públicas de turismo, os elementos conceituais apontados por Frey (2000) se edificam institucionalmente por meio do próprio Estado brasileiro com suas prerrogativas ministeriais por exemplo; da mesma forma, processualmente, as políticas de turismo, mesmo às duras penas, vêm ganhando algum destaque com medidas efetivadas pelos diferentes governos ao longo do tempo. À materialidade, cabe destacar o papel que o território brasileiro vem apresentando ora como receptáculo das ações do Estado (em sua maior parte), ora como ente que integra a sociedade à natureza. No caso do MTB, percebe-se muito mais a região como um mero desenho burocrático do que um resultado do processo de compreensão da diversidade territorial inerente às particularidades regionais.

A relação efetiva do Estado brasileiro com o turismo começa no governo Vargas - ainda na década de 1930 -, passa pelo regime militar e continua no período pós-ditadura sempre com a filosofia de que a atividade turística seria uma atividade econômica e a natureza do território brasileiro seria, nesses termos, a matéria-prima para a apropriação, uso, circulação e formação do lucro naquela atividade. Nessas diferentes épocas de gestão estatal do turismo, os planos de turismo tornaram-se efetivos a partir da década de 1970 e ganharam mais ênfase a partir do paradigma da sustentabilidade no início dos anos 1990 (SERRA, 2017).

Já é no segundo mandato do governo Fenando Henrique Cardoso que a atividade turística ganha notoriedade e uma estabilização no que concerne à efetividade de uma política pública com o Programa Nacional de Municipalização do Turismo - PNMT, que, à época, representava a descentralização da gestão dessa atividade e colocava em evidência o papel dos municípios como gestores e como agentes de deliberação do turismo em um nível local.

Estas especificidades foram consideradas no governo Luiz Inácio Lula da Silva, que, na tentativa, também, de uma descentralização, instituiu, no ano de 2003, o Programa de Regionalização do Turismo: roteiros do Brasil (PRT). No entanto, tal política federal assume uma postura contraditória no que diz respeito ao sentido real de região. Ainda sobre a ideia de Serra (2017), afirma-se que, para o governo, a região turística seria a soma dos recortes espaciais dos municípios (pelo efeito da contiguidade espacial) e não, necessariamente, pela integração política, cultural e econômica entre eles (HAESBAERT, 2010). Por outro lado, o PRT, preconiza que essa ideia de regionalização inaugura uma inclusão social nos termos do planejamento do turismo, o que, de outra forma, coloca em xeque as assertivas dessa política quanto a sua efetividade prática.

Do ponto de vista mais crítico, as ideias retratadas processualmente e institucionalmente nos documentos públicos sobre o turismo no Brasil encontram em Dias e Matos (2012) o debate sobre o município numa relação política-administrativa Para esses autores: "o município brasileiro é uma entidade política e não uma corporação administrativa” (DIAS e MATOS, 2012, p.31). Neste sentido, uma política de turismo que tome o município apenas como um recorte administrativo não pode lograr bons frutos, pois não consegue efetivar, na realidade de um planejamento e de uma gestão, as dimensões de forma intercalada.

Ainda sobre o debate acerca do município, há três elementos essenciais para seu funcionamento: território, população e o governo. Essa tríade não pode ser analisada isoladamente, mas em conjunto; pois, tais elementos se complementam, tal como na tríade que Steinberger (2013) apresenta em seu texto "A inseparabilidade entre Estado, políticas públicas e território". Nele, a autora alega que o Estado e a iniciativa privada conduzem o mercado mundial, com suas políticas públicas produzidas em uma dinâmica de inseparabilidade de um modelo híbrido, como ela própria afirma, e que também se forma uma tríade território, políticas públicas e Estado, mais uma vez reforçada pela inseparabilidade descrita por Steinberger (2013); pois, o Estado organiza o território das políticas

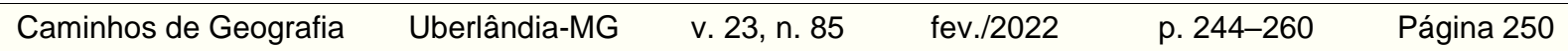


públicas, e, da mesma forma, o território, sob esta perspectiva, vincula-se estritamente às deliberações do Estado a fim de que as políticas públicas sejam efetivadas.

Os três elementos no território municipal têm o papel fundamental de desenvolvimento local da atividade econômica e essa atividade direciona os agentes sociais locais, públicos e privados, a fim de organizarem o espaço e os interesses coletivos da população. Isso esclarece, em grande medida, o comportamento dos agentes do turismo em Marabá, pois a concentração das atividades turísticas da região que o município está inserido estão, quase todas, voltadas para a cidade de Marabá. Não sem menos, tais situações direcionam como os agentes exercem seus papéis de acordo com suas representatividades. Há, então, uma problemática pública, que resulta na não regionalização do turismo em toda a região turística. Da mesma forma, pode-se dizer que o MTB não consegue um estabelecimento devidamente processual porque há uma incongruência entre os agentes-atores do turismo no âmbito da organização e decisão das atividades referentes à política do MTB. O "problema público" do qual se retrata em Secchi (2013) não ultrapassa o nível da mera formalidade política a fim de alcançar a realidade. ${ }^{6}$

A política turística deve estar voltada para a busca de diminuição das desigualdades sociais e regionais, além de promover o desenvolvimento econômico e social. É nesse sentido que o Estado deve corrigir suas falhas e reforçar seus aspectos positivos. Os locais onde o turismo se torna um gerador de renda precisam de acompanhamento de desenvolvimento turístico do impacto - positivo ou negativo ${ }^{7}$-que se refletem na realidade regional e/ou local (DIAS e MATOS, 2012). Por esta razão, a formação da 'agenda' vem a ser um elemento essencial para a organização do território e das cidades. A agenda tem a função de determinar o que será incluído ou não por meio dos agentes que atuam no poder político. Para o caso de Marabá, a agenda formal ou institucional é a melhor opção, pois ela é:

\begin{abstract}
"Aquela que elenca os problemas ou temas que o poder público já decidiu enfrentar; em outras palavras, é formada por temas de que o governo se ocupa de forma regular, através do trabalho permanente das instituições políticas administrativas; sua tendência é crescer e perpetuar-se, a menos que uma situação de crise consiga que se produza um reajuste (DIAS e MATOS, 2012, p. 71)".
\end{abstract}

O modelo de Kingdon, apresentado por Capella (2018), enfatiza atores visíveis e atores invisíveis. No contexto em que essa autora apresenta tais ideias, estes atores são representados por cargos importantes e decisivos como, por exemplo, atores do Poder Legislativo como senadores e deputados, além da mídia e da opinião pública. Além disso, há o grupo em que as influências sobre a geração de alternativas e soluções dizem respeito aos servidores públicos, analistas de grupos de interesse, assessores parlamentares, acadêmicos, pesquisadores e consultores. Em resumo, os atores visíveis são participantes na definição da agenda governamental, enquanto os atores invisíveis, por outro lado, são determinantes na escolha de alternativas, atuando principalmente na agenda de decisão. No momento atual, os agentes ligados ao turismo em Marabá estão incluídos neste modelo; pois, a ausência de formulações de agendas no município configura uma dinâmica contraditória no território, no qual a desigualdade regional é cada vez mais perceptível.

Ainda no que concerne à questão 'agenda' da política pública, Mellazo (2010) fornece uma análise necessária para este tema a fim de que se possa tornar explícita duas condições: o caráter coletivo e o caráter redistributivo. Para Melazzo (2010), ainda que seja comum, não se pode tomar o Estado como o único agente das políticas públicas. A partir desse raciocínio, podemos dizer que incorremos no perigo do centralismo das decisões, emanadas exclusivamente de um único agente. A presença de outros agentes na composição das políticas públicas não garante apenas a ação democrática (no sentido de prever e viabilizar a participação de outros representantes); mais do que isso, o caráter coletivo permite, em tese, que as deliberações sejam também oriundas de outras coletividades, requalificando, assim, a geopolítica de decisões na administração pública: "este processo de 'conversão' de decisões privadas em ações públicas se dá através daquilo que a literatura passou a denominar de grupo de interesses" (MELAZZO, 2010, p. 17).

Obviamente que a situação particular em que Marabá está situada, no que se refere ao conjunto de decisões da atividade turística, discussões como o centralismo de decisões são essenciais na tomada

\footnotetext{
${ }^{6}$ Ver Steinberger (2017), por exemplo, quando esta autora aprofunda o debate das políticas públicas a partir da participação do que ela classifica como agentes-atores das políticas públicas espaciais.

${ }^{7} \mathrm{Em}$ alguns casos, o impacto negativo reflete na realidade econômico-social de determina região, como: o aumento dos preços no mercado alimentício, casos de prostituição infantil, degradação da biodiversidade entre
} outros

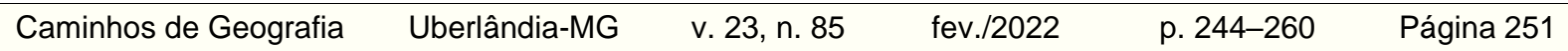


de uma 'geografia política', em que são os agentes da atividade turística que, diante das problemáticas expressas na realidade, criam mecanismos que revelam a espacialidade do poder em meio às relações de poder estabelecidas entre os representantes de setor. Não se trata, nesses termos, de compreender, ipisis literis, quais os elementos técnicos presentes no MTB aplicados na realidade regional onde Marabá é centro. Porém, os mecanismos políticos advindos dos representantes exprimem valores dos segmentos econômicos mais fortes, mesmo em uma escala municipal.

\section{OS AGENTES DO TURISMO EM MARABÁ PELO MTB: DISCURSOS E A FORÇA DA TECNOCRACIA NA TOMADA DE DECISÕES.}

Diante do cenário de elaboração e desenvolvimento de políticas voltadas para a atividade turística, no Pará, por meio do decreto n. 001/2009, criou-se a regionalização do turismo no estado, com 12 regiões de planejamento (PARÁ, 2009). Nesta resolução, a institucionalização das regiões turísticas adequou as regiões-polo de turismo ao Decreto estadual n. 1.006, de 19 de junho de 2008 (PARÁ, 2008) ${ }^{8}$, que trata da regionalização do território do Pará para o planejamento e gestão. Nestes termos, a região se tornou critério de recorte territorial (SERRA, 2017). Porém, como já fora destacado anteriormente, a ideia de recorte territorial para a região se estabelece, apenas, de forma administrativa, sem o efeito regional, ou seja, sem a interação entre o que se planeja e o espaço real, o que vem a promover uma autêntica incongruência regional, bem como da pouca ou nula efetividade de uma política pública. No ano de 2019, com a atualização do MTB, de acordo com a Portaria MTur no 192, de 27 de dezembro de 2018 (BRASIL, 2019), estas regiões passaram de seis para quatorze regiões turísticas. Nessa atualização, a "região-polo" Araguaia-Tocantins passou a ser a Região Turística Carajás, tais como apresentados nas Figuras 2, 3 e 4:

Figura 2 - Mapa da região-polo turística Araguaia-Tocantins, de acordo com informações da política paraense de turismo, 2009 -2019.
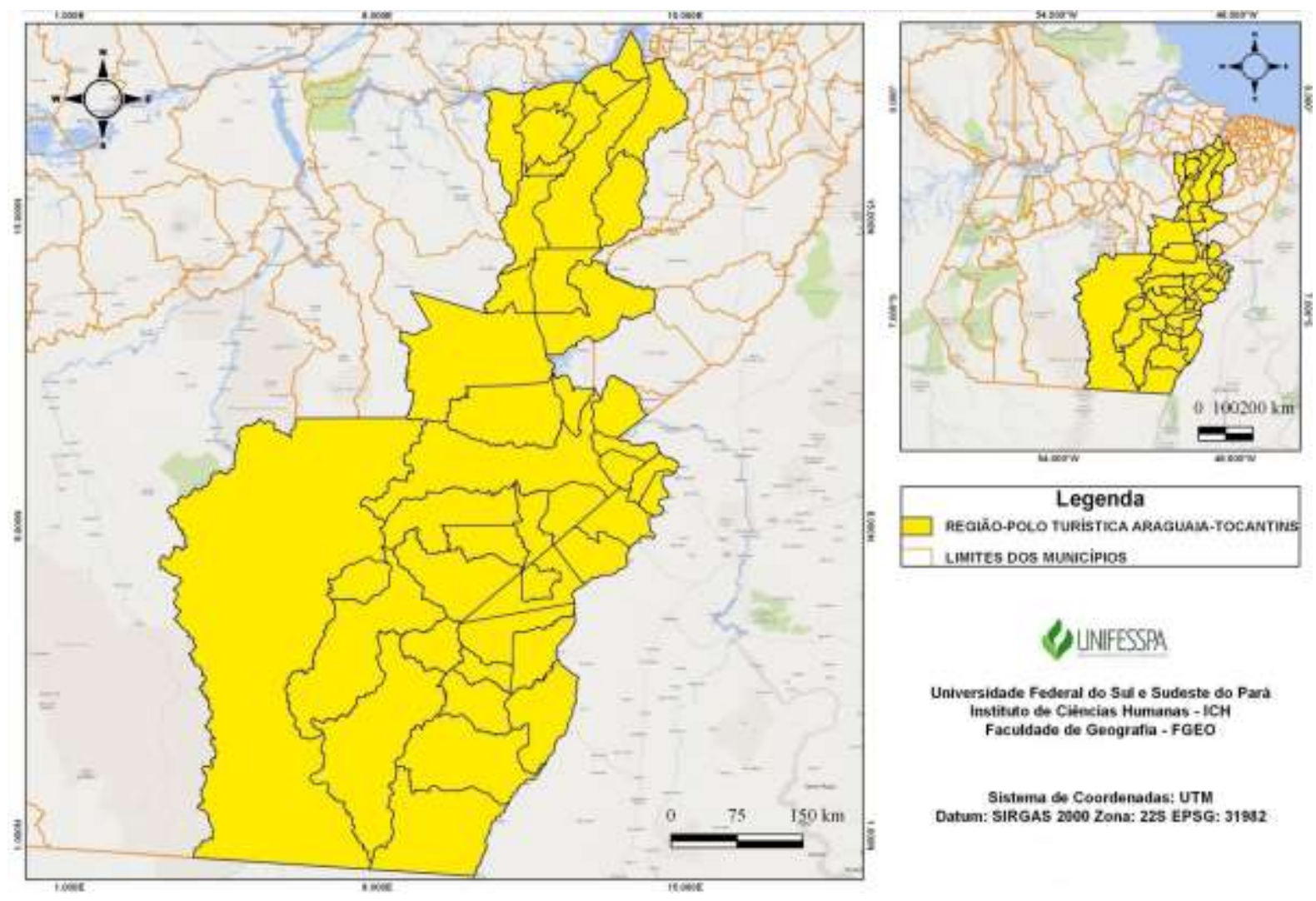

Fonte - IBGE, 2019.

\footnotetext{
${ }^{8}$ Denominação dada ao recorte político-administrativo utilizado no decreto, o que não representa a força
} conceitual do termo.

v. 23, n. 85

fev./2022

p. 244-260

Página 252 
Figura 3 - Mapa da região turística Carajás, a partir da publicação da portaria n. 164, Setur -PA/ GEPS, de 14 de junho de 2019.
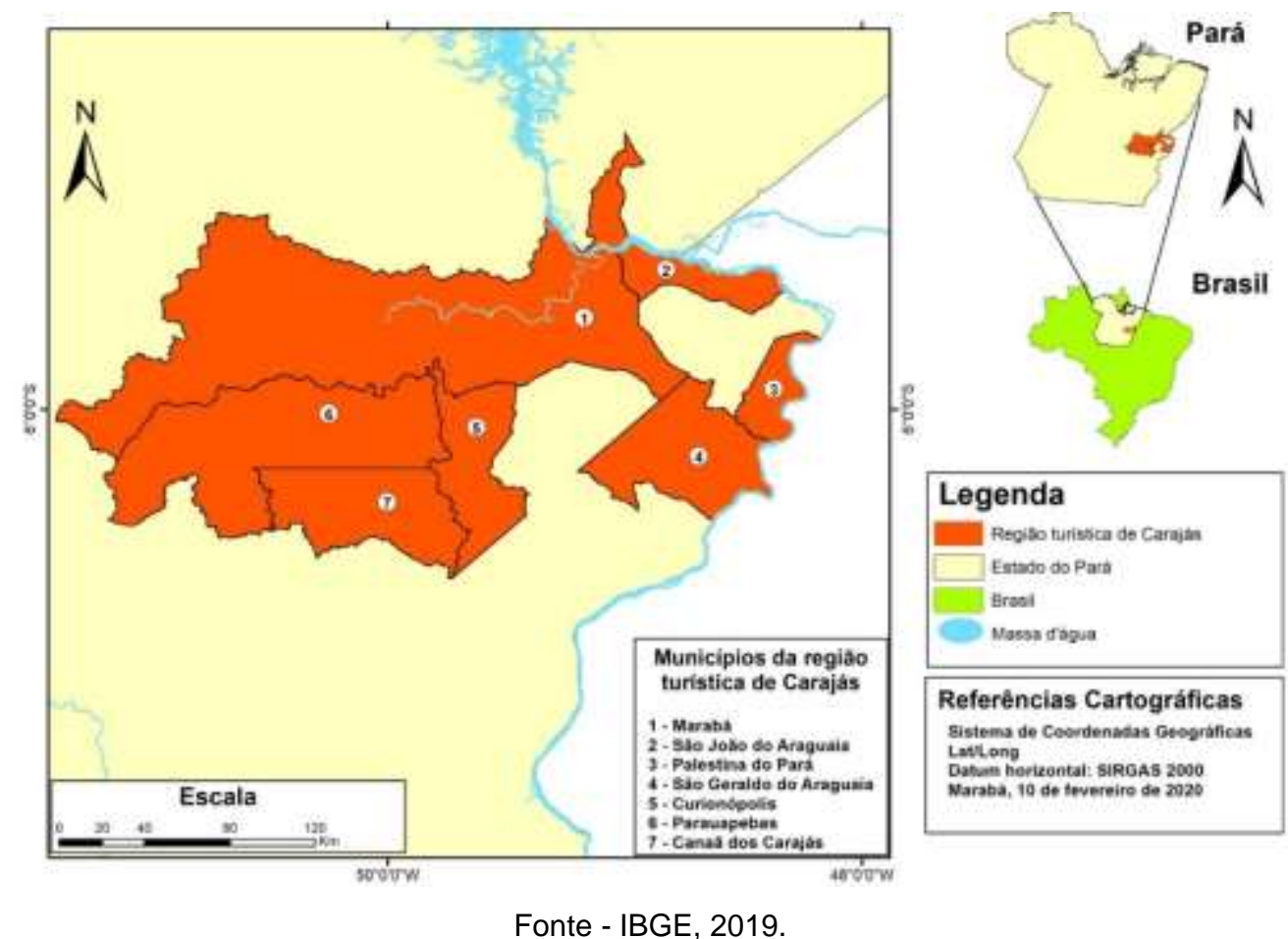

Figura 4 - Mapa dos municípios que ainda não conseguiram se inserir no Mapa do Turismo Brasileiro e municípios que já integram o MTB, Região Carajás, 2019.

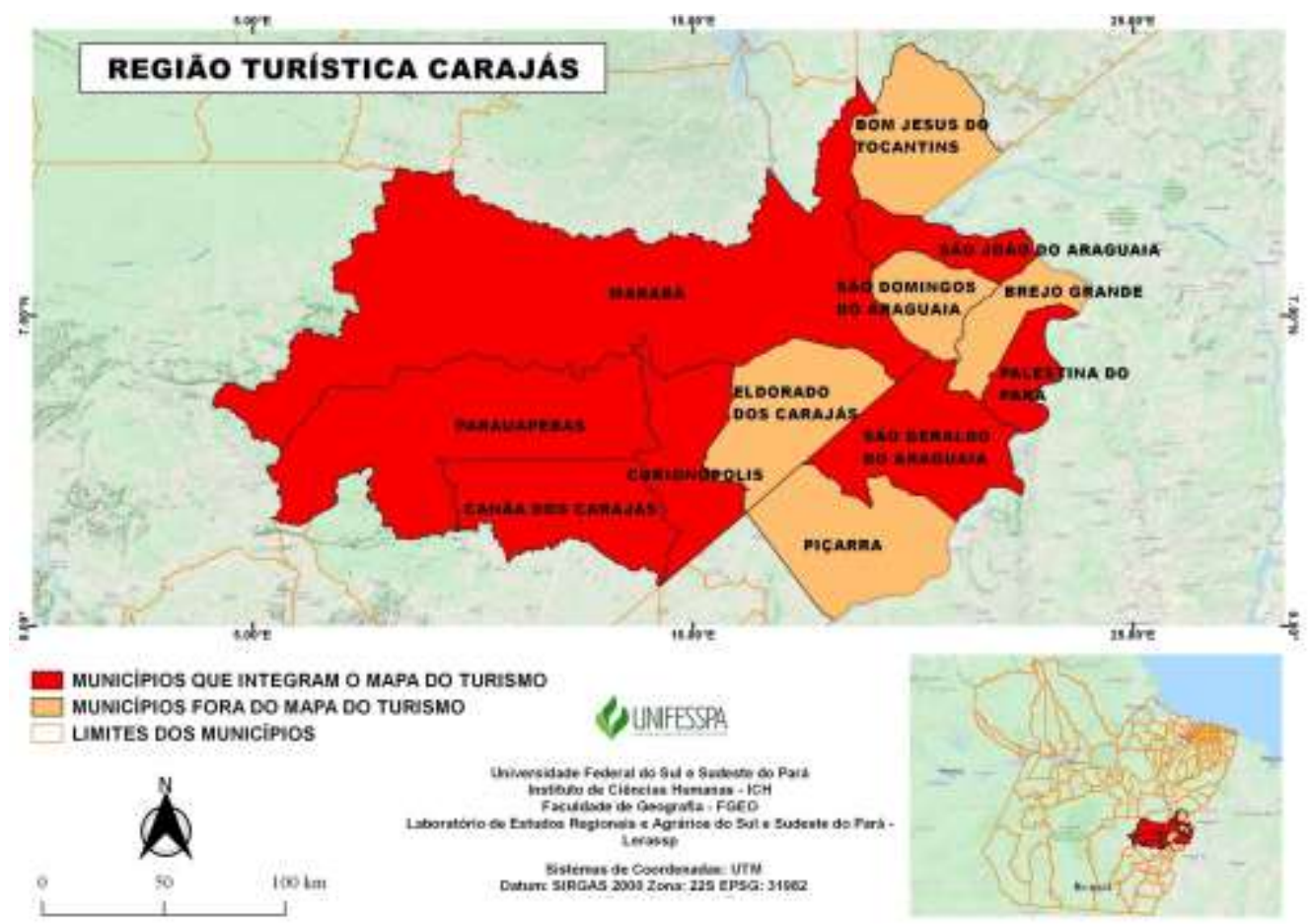

Fonte - IBGE, 2019.

Em todos os três mapas, a extensão territorial se tornou um critério muito ressaltado e muito criticado pelos agentes de turismo que reivindicaram a mudança do recorte territorial com o discurso de que a

$\begin{array}{lllll}\text { Caminhos de Geografia } & \text { Uberlândia-MG } & \text { v. 23, n. } 85 & \text { fev./2022 } & \text { p. 244-260 Página } 253\end{array}$


relação entre os municípios do mapa 1 não era possível, principalmente, por causa da distância entre Marabá e o Baixo Tocantins (situado ano norte de Marabá), por exemplo. Tal situação foi comentada em entrevista feita como secretário municipal de Indústria, Comércio, Mineração e Turismo de Marabá (Sicom). O mesmo secretário de turismo e, também, atual interlocutor da Região Turística Carajás no Pará, analisa a situação como um problema de logística no qual, dentro do estado do Pará, não há como integrar uma região turística com uma dimensão territorial extensa em um roteiro turístico. Nas palavras dele:

Nós temos uma particularidade da nossa dificuldade, primeiro que eu considero logística, eu tenho certeza que tem cidades aqui com uma riqueza de cultura (...) Cametá tem um carnaval que todo mundo fala, Cametá tá no nosso polo, aí a pergunta que eu faço é o seguinte: ninguém chega em Cametá daqui? Não chega! Você só chega lá por cima, por Belém e mesmo assim com muita dificuldade (...), mas, como é que eu integro? Eu não consigo levar um cidadão de Marabá até lá, a não ser que ele esteja com aquela pré-disposição de querer conhecer mesmo sabendo que vai demorar (sic) (Secretário de Turismo de Marabá e interlocutor da Região Turística Carajás. Entrevista concedida no dia 11 de julho de 2019).

A logística, tomada como 'problema' pelo entrevistado sobrepõe-se às relações políticas que poderiam reconfigurar novas estratégias de mobilidade, as quais, poderiam servir como ponto de partida para um debate de uma agenda regional do turismo, independentemente de seu arranjo territorial. Deve-se deixar claro, evidentemente, que o problema exposto pelo entrevistado é real, o que impossibilita traslados entre os municípios citados por ele. Contudo, o que chama a atenção é o fato de não se evidenciar as relações intra-regionais, as quais podem auxiliar na composição de medidas coletivas e que podem beneficiar as diferentes realidades singulares do território paraense.

No mapa 2, a região, já em seu momento atual, apresenta dois pontos importantes: a) doze munícipios integram a Região Turística de Carajás (RTC); b) apenas sete municípios fazem parte do Mapa do Turismo Brasileiro (mapa 3). Essa diferença não se manifesta apenas cartograficamente (tal como exposto nas representações anteriores). Mais do que isso, os problemas se reverberam político-espacialmente, pois, dada as considerações alegadas por agentes centrais da política de turismo, tal como o secretário de turismo de Marabá, as relações entre os próprios integrantes mostram-se fragilizadas, o que acaba por refletir uma espécie de 'quadro-mosaico' de municípios com o pretenso discurso de integração regional, a fim de se manterem dentro dos critério do MTB; o vácuo entre a criterização da política do governo federal e a realidade regional onde Marabá se situa ganha contornos políticos, administrativos, de gestão e planejamento próprios, revelando-se muito mais inconsistências do que eficiências.

A aplicabilidade do Programa em Marabá, desde o princípio, foi falha em questões de regionalização. Por outro lado, alguns dos critérios mais importantes para que um munícipio integre o 'Mapa', já estava em vigor em Marabá; porém, com poucas ou sem atividades estritamente vinculadas ao MTB: a) a existência de um órgão de turismo ou que seja relativo à secretaria de turismo e b) a existência e permanência de Conselho Municipal de Turismo. Para o caso de Marabá, há o Comtur.

Os critérios publicizados pelo MTB surgem em um cenário em que cada vez mais as gestões públicas são cobradas por haver a necessidade de participação da sociedade civil, por meio de segmentos representativos ou, de forma direta, pela participação ativa da sociedade interessada. No entanto, não necessariamente um novo contexto de planejamento e gestão, que implique em mudanças necessárias, tais como a participação das pessoas em momentos deliberativos, significa a plenitude da gestão. Dias e Matos (2012), por exemplo, defendem os Conselhos como medida de participação da sociedade, pois, segundo esses autores, por esse critério, garante-se a diversidade e a interação entre diferentes segmentos da sociedade; eles acrescentam ainda que essa ação obriga os governos "a prestarem contas de suas ações num foro institucionalizado" (DIAS e MATOS, 2012, p. 210).

Por outro lado, Comerlatto et al. (2007) afirmam que não adianta haver uma demarcação administrativa, tais como um Conselho Municipal se não houver a prática da intersetorialidade. Esta última seria, esses autores, condição para efetivar o diálogo entre os diferentes. Por este critério, otimizam-se os recursos e, ao mesmo tempo, garante-se uma visão integrada dos problemas munícipes, pois a aprendizagem acaba se tornando um elemento definitivamente global, e não de apenas setores específicos da sociedade. Sendo assim, ao ser ponto de referência para o planejamento e a gestão de políticas de turismo, o MTB - pode-se afirmar - já se apresenta muito mais como um desafio a ser vencido do que propriamente uma política que passe a solucionar problemas tangíveis à atividade turística nas regiões Sul e Sudeste do território paraense.

$\begin{array}{llllll}\text { Caminhos de Geografia } & \text { Uberlândia-MG } & \text { v. 23, n. } 85 & \text { fev./2022 } & \text { p. 244-260 } & \text { Página } 254\end{array}$


Outra questão necessária ao debate do MTB na região de Carajás retoma o que já fora discutido na primeira seção deste trabalho, qual seja a da importância de Marabá como cidade central na difusão das informações que regem o tecido político-econômico regional. Neste caso, a influência do representante político de Marabá na representatividade dos assuntos regionais é uma expressão da psicosfera que um lugar pode emitir em situações de decisão para a sociedade (SANTOS, 1996).

Durante o biênio 2017/2019, o Comtur, sendo uma instância de governança local que possui funções consultivas e deliberativas como diretrizes centrais, tratou de questões normativas e regimentais que o Conselho precisa ter, uma delas foi firmar a relação inter-institucional com a Secretaria de Indústria, Comércio, Mineração e Turismo de Marabá, medida essa que só fez reforçar a interdependência política entre tais instituições; tal condição política foi reafirmada na posse dos novos conselheiros para o biênio 2019-2021.

Retomando-se o debate sobre a centralidade dos lugares e ao associar tal condição conceitual à realidade regional de Marabá, percebe-se a recorrência desses elementos em discursos dos agentes que lidam com a atividade turística na cidade. Nota-se, a partir de seus argumentos, que a dimensão espacial de Marabá, com sua pujança econômica relativa para a região, reforça o sentimento de centralidade, expresso, também, nas instituições representativas do turismo, a exemplo da Secretaria de Turismo e do Conselho Municipal de Turismo. Um dos temas que movimenta o cenário econômico do turismo e que é motivo de destaque nas políticas do setor é o chamado 'turismo de negócios', ainda que seja um conceito controverso, ele acaba por se tornar um tema estruturante nos discursos e que, por fim, indiretamente, pode compor o cenário de uma agenda de política pública:

\begin{abstract}
O turismo, hoje, é a grande alavanca da economia mundial, né? Então, você tem... ele é subdivido em diversas áreas, turismo de negócios, turismo de lazer, turismo de eventos, dentro desses ainda tem subdivisões, né, por exemplo: você pode pegar dentro do lazer, você tem os clubes temáticos, tem os navios, enfim, existe uma gama, uma variedade muito grande de oferta e produto turístico (...) particularmente aqui pra nossa região, nós temos o principal foco do turismo que nos dá sustentação é o turismo de negócios, depois vem o turismo de eventos e por último o turismo de lazer. Então, o que dá sustentabilidade ao setor hoteleiro é, do modo geral, é o turismo de negócios, onde você vai ter $70,75 \%$ de sustentabilidade do setor em cima desse perfil do turista de negócios (...) o turismo de eventos, a nossa cidade, na nossa região, ele basicamente é um turismo regional, então, ele é forte? É! Mas, ele não tem a potencialidade de atrair outros estados do Brasil para esses eventos que são shows, palestras no Centro de Convenções, eventos religiosos, enfim... é, tudo que a cidade oferece, ela oferece sempre a nível regional (presidente do Sindicato dos Hotéis de Marabá. Entrevista concedida no dia 13 de junho de 2019).
\end{abstract}

Percebe-se na fala do entrevistado que não há uma comprovação estatística do "turismo de negócios", não caracterizando, assim, a economia de Marabá em razão desse tipo de turismo que, no conceito técnico, é muito duvidoso (SERRA, SOUZA, RIBEIRO, 2012). Nessas condições, o sistema turístico local, em suas diferentes partes, pode causar uma alteração e afetar o todo, ou seja, o produto turístico local - a cidade (DIAS e MATOS, 2012), o assim chamado "turismo de negócios" só se estabelece no discurso. De toda forma, para que uma ideia como essa seja disseminada a partir de agentes representativos da política de turismo, significa dizer que a centralidade de uma cidade como Marabá faz com que haja uma reverberação de discursos, ainda que não haja uma correlação de ideias com sua espacialidade.

O que o presidente do Sihoma se refere diz respeito a uma característica típica de cidades médias do porte de Marabá, como já fora citado em outro momento. Nestes termos, uma cidade com essa qualidade influencia as demais cidades de sua rede pelo fato de haver uma concentração de serviços, bem como logística. Da mesma forma, Marabá é um centro regional no qual há diversos empreendimentos econômicos, os quais se irradiam regionalmente. Possui um entrecruzamento de redes aérea, ferroviária e rodoviária (em pequena escala, hidroviária). Dessa forma, Marabá - por ter uma economia relacionada ao agronegócio, mineração, serviços e comércios - dá suporte para os municípios próximos, oferece um leque de possibilidades e opções para todos os tipos de circulação econômica. No entanto, a força econômica de Marabá não se traduz na atividade turística. Em outras palavras, a ampla oferta de serviços não pode - per se - ser caracterizada como um atrativo turístico, ainda que haja uma intensa mobilidade de pessoas, mercadorias e serviços; mesmo assim, os agentes institucionais conduzem a política de turismo no município a fim de fazer valer as diretrizes do 'Mapa do Turismo Brasileiro' ao se justificar o critério orçamentário.

$\begin{array}{llllll}\text { Caminhos de Geografia } & \text { Uberlândia-MG } & \text { v. 23, n. } 85 & \text { fev./2022 } & \text { p. 244-260 } & \text { Página } 255\end{array}$


Como fora dito anteriormente, o Comtur é um órgão que trabalha em conjunto com a Secretaria de Turismo. Esses órgãos planejam e realizam atividades relativas aos eventos turísticos no munícipio de Marabá. Através de reuniões ordinárias, realizadas a cada primeira terça-feira ou quinta-feira do mês, e extraordinárias a qualquer momento, o Conselho discute pautas que envolvem entidades públicas e da iniciativa privada.

Ao se apropriar de Frey (2000), por exemplo, o autor parte da ideia de que "as disputas políticas e as relações das forças de poder sempre deixarão suas marcas nos programas e projetos desenvolvidos e implementados" (FREY, 2000, p. 219). Por esse pressuposto, permite-se dizer que a análise do peso da participação dos representantes do Comtur se manifesta da seguinte forma: "quem é?". Fica evidente, assim, a tecnocracia na decisão e participação destes agentes. São agentes com um "conhecimento superior" que, hierarquicamente, detém um poder político mais forte em detrimento dos demais que possuem o poder de decisão - ainda que haja um debate político entre os representantes a fim de tomar a decisão final e participar ativamente -, mas que não é suficiente para garantir a efetividade de interesses de todos (SOUZA e RODRIGUES, 2004).

Guimarães (2003 apud SPOSITO, 2007) esclarece, perfeitamente, a capacidade de agir e decidir dos atores:

[...] quanto mais um ator político é capaz de atuar entre escalas, maior o seu poder de decisão sobre a produção do espaço. Da mesma forma, a importância política está relacionada à complexidade da síntese de escalas que este proporciona, potencializando a capacidade de agir de determinados autores (GUIMARÃES apud SPOSITO, 2007, p. 45).

Nesse contexto, o poder de influência econômico-política referente ao turismo, na cidade de Marabá, protagoniza-se, por exemplo, pelos representantes de empresas de organizações de eventos; representantes do denominado Sistema S (Sebrae, Senac, Sest Senai e Sesc); representantes da Secretaria Municipal de Indústria e Comércio (Sicom); representantes da Secretaria Municipal de Turismo; representantes do Sindicato dos Trabalhadores e Hotel de Marabá (Sihoma); e representantes do Associação Comercial e Industrial de Marabá (Acim).

Estes agentes são protagonistas e os demais são coadjuvantes, configurando-se, deste modo, em uma relação tecnocrata de decisões políticas do espaço turístico, ou seja, coadjuvantes (representações políticas com menor influência política nas decisões, mas com direito a voto), apenas figuram como "estatística". É, portanto, nesse campo que o establishment do turismo se estabelece em Marabá, através do poder de decisão. Logo, é notório que haja uma manifestação diferenciada daqueles que não têm uma visão técnica e, desse modo, uma contradição interna.

Associadas a isso, percebe-se que as decisões não conseguem alcançar uma efetiva regionalização devido à concentração das atividades econômicas em âmbito local, ou seja, o resultado das políticas de turismo restringe-se à cidade de Marabá, não havendo uma difusão e nem uma coesão regional das políticas de turismo. Há de se considerar também que, no que se refere ao Comtur como uma instância de governança local, é importante deixar claro que este órgão não faz uma abordagem crítica da concepção de turismo veiculada pelo MTB. Os envolvidos no Conselho, incluindo a presidência, não tem o conhecimento prévio do que seja o Programa Mapa do Turismo Brasileiro ou do Programa de Regionalização do Turismo, apenas três dos entrevistados souberam responder o questionamento acerca do conhecimento sobre o Programa, inclusive a Secretária Adjunta do Secretário de Turismo é uma turismóloga e quando questionada sobre qual o legado ela gostaria de deixar ao fim da sua gestão, o seu maior desejo é que se consiga, de fato, exercer a regionalização e que, agora, com a atualização do Mapa isso seria possível.

\section{CONSIDERAÇÕES FINAIS}

Considera-se, por fim, neste trabalho que, primeiramente, as políticas públicas espaciais dos agentes do turismo em Marabá se traduzem na tentativa de uma regionalização do turismo através dos critérios exigidos no Programa Mapa do Turismo brasileiro. No entanto, a concepção das referidas políticas não se efetiva na realidade devido haver uma concentração das políticas em âmbito local, notadamente na cidade de Marabá. Esse ponto tem relação econômica e histórica com Marabá, na condição de cidade média.

Marabá é, historicamente, uma região moldada pelas relações econômico-sociais que se torna o destino de muitos, não para o turismo, mas pela rede de serviços e comércio que a cidade oferece, o

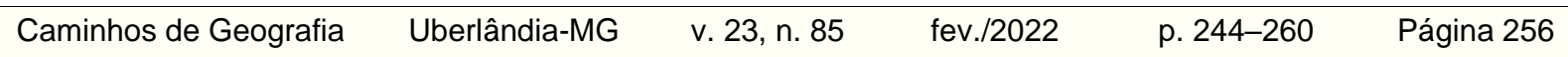


que acaba por reforçar o poder de concentração na cidade e não de difusão regional. Como agregadora, Marabá acabou construindo uma geografia estratégica na região Sul-sudeste do Pará, redimensionando a hierarquia urbano-regional. Esses elementos, deve-se destacar, não são resultados da força econômica de uma atividade como o turismo para esta realidade espacial, e sim o inverso. A economia de múltiplos serviços soergueu o setor classificado como turístico. Salienta-se, sobretudo, que o fato de ser centro, não significa que Marabá deva exercer um papel concentrador na espacialização de uma política de turismo tal como o MTB. Mais do que isso, a centralidade dessa cidade média deve servir de elo regional entre localidades integrantes da política federal em questão, o que pode reforçar um papel decisivo na governança regional entre os pares integrantes. Essa estratégia deveria ser mais praticada, em tese, em regiões pobres, tais como a Amazônia, em que o processo de equilíbrio de forças é frágil quando não se vislumbra um trabalho coletivo, para além dos contratempos de planejamento e gestão individualizados. Dessa forma, as incongruências regionais seriam, ao menos, mitigadas.

A simbiose entre a economia e a economia do turismo (IPEA, 2015) não pode ser um dado descolado da realidade econômica de Marabá, pois, da mesma forma como se perceba na escala nacional, a economia brasileira impulsiona o turismo, resguardada suas particularidades regionais, assim como os setores econômicos envolvidos.

Em segundo lugar, a ausência de uma formação de agenda institucional, para que as políticas públicas de turismo funcionem de fato no território é um dos principais efeitos que refletem na realidade espacial que o problema não está sendo solucionado, mas sim omitido. Isso se reflete, por sua vez, na não prioridade da atividade turística (e seus correlatos) na agenda de uma prefeitura, tal como a de Marabá. Percebe-se, muito mais, um esforço espaçado de setores empresariais e parte do setor público, do que uma força conjunta, que possa evidenciar o uso apropriado de recursos turísticos em Marabá.

Além disso, ainda que os agentes de turismo atuem na condição de promotores dessa atividade, há uma forte segmentação no que diz respeito ao papel dos agentes. De um lado, há uma força do discurso técnico oriunda dos que são -tradicionalmente- representantes de um circuito econômico mais distinto, tais como os representantes dos hotéis e a própria prefeitura. Por outro lado, há uma pouca ou nula participação de agentes considerados de pouca expressão política ou que não possuem o mesmo teor técnico do discurso político, tais como os representantes dos barqueiros e dos artesãos. Tal distinção, ainda que não se prefigure como critério de uma política pública como a do MTB, aponta para um tratamento desigual entre desiguais e diferentes na composição do quadro de representantes dos órgãos de turismo no município de Marabá. Independente da configuração político-espacial, o papel dos agentes produtores da política de turismo em Marabá é o de executar ações do governo federal sem atentar para as particularidades regionais inerentes à região de Carajás, as quais, emanam características que, nem sempre, respondem aos anseios de uma política tal como o MTB. Esse modus operandi se reverbera, necessariamente, nas relações entre os agentes, bem como no espaço geográfico, sendo numa dimensão local ou ainda regional, em ambos os casos, a relação local-regional incorpora decisões de âmbito federal de forma fragmentada.

Em terceiro lugar, percebe-se uma incongruência regional no que refere à concepção do MTB e sua efetividade na região onde Marabá está inserida, em que se constata uma não regionalização ou, dito de outra forma, cria-se uma região turística sem seus reais efeitos regionais. Isso se deve pelo fato de que o recorte regional feito pelo governo federal e que, na base dessa política funciona como um dos critérios, explica-se pela soma dos municípios que possuem uma contiguidade territorial e não uma relação inter-regional dos fatos e fenômenos que podem vir a causar um efeito regional a partir da diversidade cultural, social e política entre os entes administrativos. Tal evidência pode ser comprovada nas breves falas transcritas dos entrevistados.

Ainda no que se refere ao MTB, cabe registrar que tal política espelha, mais uma vez, uma dissonância percebida não só a partir do ponto de vista das ideias contidas em um documento público, mas, em sua geografia, a qual, para o território brasileiro, não se dá conta de sua diversidade territorial, de suas diferenças entre as realidades, constituídas que são pelo lastro histórico da formação regional. Estes últimos elementos, sim, deveriam formar uma base importante para se desenvolver um tipo de turismo regional, aquele em que o turista reconhece as particularidades e singularidades distintas de seu espaço emissivo. A Amazônia é, por sua vez, representante deste fato.

$\begin{array}{llllll}\text { Caminhos de Geografia } & \text { Uberlândia-MG } & \text { v. 23, n. } 85 & \text { fev./2022 } & \text { p. 244-260 } & \text { Página } 257\end{array}$




\section{REFERÊNCIAS}

BECKER, B. Geopolítica da Amazônia: a nova fronteira de recursos. Rio de Janeiro: Zahar, 1982.

BECKER, B.; MIRANDA, M.; MACHADO, L. Fronteira amazônica: questões sobre a gestão do território. Brasília: Editora UNB. Rio de Janeiro: Editora UFRJ, 1990.

Amazônia. 6. ed. São Paulo: Ática, 1998.

A urbe amazônida: a floresta e a cidade. Rio de Janeiro: Garamond, 2013.

BRASIL. Plano nacional de turismo: diretrizes, metas e programas. Brasília: Ministério do Turismo, 2003.

Programa de Regionalização do Turismo - Roteiros do Brasil. Diretrizes Operacionais. Brasília: Ministério do Turismo, 2004.

Ministério do Turismo. Programa Mapa do Turismo Brasileiro. Brasília: MTur, 2019. Disponível em: <http://www.regionalizacao.turismo.gov.br>. Acesso em 10/02/2020.

CAPELLA, A. Formulação de Políticas. Brasília: Enap, 2018.

COMERLATTO, D.; COLLISELLI, L.; KLEBA, M.; MATIELLO, A.; RENK, E. Gestão de políticas públicas e intersetorialidade: diálogo e construções essenciais para os conselhos municipais. Revista Katálysis. Florianópolis, v. 10, n. 2, jul/dez 2007, p. 265-271. https://doi.org/10.1590/S1414$\underline{49802007000200015}$

CORRÊA, R. Espaço: um conceito-chave da Geografia. In: CASTRO, I.; GOMES, P.; CORRÊA, R. (Orgs.). Geografia: conceitos e temas. 2. ed. Rio de Janeiro: Bertrand Brasil, 2000, p. 15-47.

. Construindo o conceito de cidade média. In: SPOSITO, M. E. B. (Org.). Cidades médias: espaços em transição. São Paulo: Expressão Popular, 2007. p. 23-35.

CRUZ, R. Políticas públicas de turismo no Brasil: território usado, território negligenciado. Geosul, Florianópolis, v. 20, n. 40, p. 27-43, jul./dez. 2005.

DIAS, C. V. Marabá: centro comercial da castanha. Revista Brasileira de Geografia, Rio de Janeiro, ano 20, n.4, p.383-425, 1958.

DIAS, R.; MATOS, F. Políticas públicas: princípios, propósitos e processos. São Paulo: Atlas, 2012.

EMMI, M. A oligarquia do Tocantins e o domínio dos castanhais. Belém: UFPA/NAEA, 1999.

FREY, K. Políticas públicas: um debate conceitual e reflexões referentes à prática da análise de políticas públicas no Brasil. Planejamento e Políticas Públicas. Brasília, IPEA: n.21, jun. 2000, p.211-259.

HAESBAERT, R. Regional-global: dilemas da região e da regionalização na geografia contemporânea. Rio de Janeiro: Brasiliense, 2010.

HARVEY, D. A justiça social e a cidade. São Paulo: Hucitec, 1980.

Espaços de esperança. São Paulo: Loyola, 2004.

IBGE Instituto Brasileiro de Geografia e Estatística. Censo agropecuário 2017: resultados definitivos. Rio de Janeiro: IBGE, 2019.

Regiões de Influência das Cidades: 2018. Rio de Janeiro: IBGE, 2020, 192 p.

IPEA. Instituto de Pesquisa Econômica Aplicada. Relatório com as estimativas da caracterização da ocupação formal e informal do turismo, com base nos dados da Rais e da Pnad 2013, para o Brasil e regiões: termo de execução descentralizada n. 01/2014. Brasília: Ministério do Turismo/lpea, março, 2015.

JORNAL CORREIO DO CARAJÁS. Nova Marabá: sobram folhas e faltam nomes. Disponível em: http://www.correiodecarajas.com.br. Acesso em 22/09/2020.

MELAZZO, E. Problematizando o conceito de políticas públicas: desafios à análise e à prática do planejamento e da gestão. Presidente Prudente -SP. Revista Tópos, v. 4, n. 2, 2010, p. 9-32. 
OURIQUES, H. Produção do Turismo: fetichismo e dependência. Presidente Prudente, 2003. Tese (Doutorado em Geografia - Desenvolvimento Regional e Planejamento Ambiental) - Faculdade de Ciências e Tecnologia. Universidade Estadual Paulista, Presidente Prudente, 2003.

PARÁ (Estado). Decreto n. 1.006, de 19 de junho de 2008. Dispõe sobre a regionalização do estado do Pará e dá outras providências. Diário Oficial do Estado do Pará, Belém, PA, 20 jun. 2008. Caderno Executivo, p. 8

Resolução n. 001, de 11 de maio de 2009. Dispõe sobre a adequação dos polos turísticos às novas regiões turísticas estabelecidas no Decreto Estadual de n. 1.066, de 19 jun. 2008. Lex: Diário Oficial do Estado do Pará, Belém, p. 2. Caderno Executivo, maio, 2009.

Secretaria de Estado de Turismo. Portaria n. 164, de 14 de junho de 2019. Dispõe sobre a regionalização do turismo no Estado do Pará e dá outras providências. Diário Oficial do Estado do Pará.
Belém,
$\mathrm{PA}$,
15 jun.
2019.
Disponível

em:<http://www.jusbrasil.com.br/diarios/247116532/doepa-14-06-2019-pg-89. Acesso em: 20 out. 2020.

PEREIRA, J.; TRINDADE JÚNIOR, S. Reestruturação da rede urbana e importância das cidades médias na Amazônia Oriental. In: SPOSITO, M. (Org.). Cidades médias: espaços em transição. São Paulo: Expressão Popular, 2007. P. 313-343.

SANTOS, M. sociedade e espaço: a formação social como teoria e como método. In: Sociedade e espaço. Petrópolis: Vozes, 1979a, p. 9-27.

Economia especial. São Paulo: Hucitec, 1979b.

A urbanização brasileira. São Paulo: Hucitec, 1993.

A natureza do espaço: técnica e tempo, razão e emoção. São Paulo: Hucitec, 1996.

O espaço dividido: os dois circuitos da economia urbana dos países subdesenvolvidos. 2. ed. São Paulo: Edusp, 2002.

SECCHI, L. Políticas públicas: conceitos, esquemas de análise, casos práticos. 2. ed. São Paulo: Cengage Learning, 2013.

SERRA, H.; SOUZA, J.; RIBEIRO, W. Superando o pragmatismo econômico: redefinindo os limites do turismo a partir de uma abordagem espacial. Espaço Aberto: PPGG - UFRJ, v. 2, n.1, 2012, p. 85100.

SERRA, H. Problemas de regionalização e políticas públicas de turismo no território paraense. 316f. 2017. Tese (Doutorado em Geografia). Universidade Estadual de São Paulo/ Programa de PósGraduação em Geografia, Presidente 2017. https://doi.org/10.36403/espacoaberto.2012.2077

SOUZA, M.; RODRIGUES, G. Planejamento urbano e ativismos sociais. São Paulo: Unesp, 2004 (Paradidáticos, série sociedade, espaço e tempo).

SPOSITO, M. E. Cidades médias: reestruturação das cidades e reestruturação urbana. In: (Org.). Cidades médias: espaços em transição. São Paulo: Expressão Popular, 2007. p. 233-257.

STEINBERGER, M. (Org.). Território, Estado e políticas públicas espaciais. Brasília: Ler Editora, 2013.

STEINBERGER, M. Introdução. In: espaciais. Brasília: Ler Editora, 2017, p. 19-28.

(Org.). Território, agentes-atores e políticas públicas

TRINDADE JÚNIOR, S.; AMARAL, M.; MALHEIRO, B.; RIBEIRO, R.; RODRIGUES, J. Uma cidade média na Amazônia Oriental: a centralidade urbano-regional de Marabá no Sudeste Paraense. In: ELIAS, D.; SOARES, B.; SPOSITO, M. (Orgs.). Agentes econômicos e reestruturação urbana e regional: Marabá e Los Angeles. 1.ed. São Paulo: Cultura Acadêmica, 2016.

; RIBEIRO, R. Marabá: novos agentes econômicos e novas centralidades urbano-regionais no Sudeste Paraense. In: TRINDADE JR., S-C. C. et al. (Orgs.). Pequenas e médias cidades na Amazônia. Belém: ICSA-UFPA, 2009. p.333-59. 
TRINDADE JÚNIOR, S.; PEREIRA, J. Reestruturação da rede urbana e importância das cidades médias na Amazônia Oriental. In: SPOSITO, M. (Org.). Cidades médias: espaços em transição. São Paulo: Expressão Popular, 2007, p. 313- 342 (Coleção Geografia em Movimento).

VELHO, O. Frentes de expansão e estrutura agrária: estudo do processo de penetração em uma área da Transamazônica. Rio de Janeiro: Zahar, 1981.

WHITACKER, A. Uma discussão sobre a morfologia urbana e a articulação de níveis diferentes de urbanização. In: SPOSITO, M. (Org.). Cidades médias: espaços em transição. São Paulo: Expressão Popular, 2007. p. 139-156 (Coleção Geografia em Movimento).

Recebido em: 22/10/2020

Aceito para publicação em: 24/03/2021 